\title{
A COMPUTER MODEL TO PREDICT THE DROPLET SIZE TRAVELING DISTANCE IN NOWIND AND WINDY CONDITIONS FOR DIFFERENT NOZZLE SHAPES.
}

A. M. El-Berry' ${ }^{1}$ M. H. Ramadan', M. A. El-Adl ${ }^{3}$ and H. M. Abdel Mageed ${ }^{4}$

\section{ABSTRACT}

A finite difference numerical model was developed to determine the mean droplet size diameter at any distance from a sprinkler as a function of nozzle shape, size and pressure. Droplet size data from square, rectangle, triangle and circle nozzle orifice shapes verified the model. Data for model prediction were generated throughout lab experiments. Nozzle pressure and shape had a major influence on droplet size. Higher pressure promoted smaller droplets over the entire application profile. Noncircular nozzles had a large droplet size at the same distance from sprinkler but circular nozzle had the largest droplet size near the perimeter.

Key words: sprinkler irrigation, nozzle shape, droplet size, modeling.

\section{INTRODUCTION}

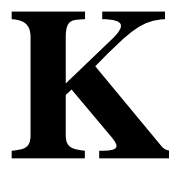
ohl (1974) studied the effects of pressure and nozzle size on the droplet size distribution from medium sized agricultural agricultural sprinklers followed the relationship of decreasing droplet size with increasing relative velocity of the water to the air. Decreasing nozzle diameter decreased mean droplet size but increasing pressure decreases mean droplet size by a great amount.

Awady (1978) set two hypotheses for droplet separation: against surface tension and against viscous shear. For surface tension, the droplet size " $S$ " varies as:

1 Prof. of Agric. Eng., Dept. of Agric. Eng. , Faculty of Agriculture, Cairo University, 2 and 3 Assoc. Prof. of Agric. Eng. Dept. of Agric. Eng., Faculty of Agriculture, Al-Mansoura University, and 4 Agric. Res. Ins., Alexandria Branch, Alexandria, Egypt 


$$
S \cong \frac{\delta}{P \tan ^{2}(\alpha / 2)}
$$

and for shear:

$$
S \cong \frac{\mu}{\sqrt{\rho P} \tan (\alpha / 2)}
$$

Where " $\delta$ " is surface tension, " $P$ " pressure, " $\alpha$ " spray cone angle, " $\mu$ " coefficient of dynamic viscosity, " $\rho$ " is the fluid density. Dimensions have to be homogeneous on both sides of the relations.

The critical state beyond 0.25 tend to separation under tension, for the following criterion ( $C_{r}$ ):

$$
C_{r}=\frac{\mu}{\delta} \sqrt{\frac{P}{\rho}} \tan (\alpha / 2) \cong 0.25
$$

David and Yuping (1989) reported that nozzle pressure had major influence on droplet size. The volume mean droplet diameter of total water applied as a function of nozzle size and pressure were determined. Higher pressure promoted smaller droplets over the application profile.

Kohl (1974) stated that the droplet mass was important specially on soils with crusting problems; it was very sensitive to water pressure. He also found that the mean size of water droplets is increasing along the trajectory distance. He also found that decreasing nozzle diameter decreased mean droplet size, while increasing pressure decreases mean droplet size by a greater amount, especially at the end of the jet. He found that droplet mass was increased fivefold with a pressure decrease from 60 to $20 \mathrm{~N} / \mathrm{Cm}^{2}(\mathrm{MPa})$. He referred that to the relationship of decreasing droplet size with increasing relative velocity of water to the air.

Droplet size is an important factor affecting the formation of "seals" on bare soil surfaces that restrict water movement into the soil. Because, small droplets possess less power when they impact the soil surface, "seals" that limit infiltration form more slowly than with larger droplets. For these reasons, it is sometimes possible to reduce runoff and erosion by converting from sprinklers that emit large droplets to ones with

Misr J. Ag. Eng., January 2009 
smaller droplets. Droplet size is especially important when sprinklers must operate in wind. Distribution patterns from sprinklers that emit smaller droplets are more subject to wind distortion and lower application uniformity. In addition, increased losses due to wind drift usually occur with small droplet sprinklers (Larry, 1988).

The soil damage hazard from large droplets is further compounded in the case of circular nozzles at low pressures due to high application rates near the perimeter (Chen and Wallender, 1985).

Heernann and Kohl (1981). stated that the droplet size distribution of sprinkler is practically important for two reasons:

I- Small droplets are subjected to wind drift, distorting the application pattern.

2- Large droplets possess greater kinetic energy which is transferred to the soil surface causing particle dislodgement and puddling that may result in surface crusting and runoff.

Higher operating pressures normally increase the volume of water applied as smaller droplets while decreasing the volume of larger droplets. A similar, but a significantly smaller effect occurs on the larger droplets (not on the volume of water) as nozzle opening size is decreased. Nozzle opening shape can have an important effect on droplet size while nozzle angle has little effect. (Larry, 1988)

Diffuse-jet nozzles; are designed so that droplets are formed at a lower pressure than with other impact nozzles. This is accomplished by using noncircular-shaped nozzle openings or turbulence inducer at the orifice to diffuse the jet as it leaves the nozzle. Diffuse-jet nozzles do not wet as large an area as do constant-diameter and constant-discharge nozzles. (Larry, 1988)

Low pressure impact sprinklers produce smaller droplets at a lower pressure than do traditional impact sprinklers which operate at $350 \mathrm{kPa}$ (50 psi) or more. This is accomplished by passing water through one or more noncircular shaped nozzles to diffuse the jet as it leaves the sprinkler. These sprinklers operate at about $240 \mathrm{kPa}$ (35 psi) and normally have a wetted diameter of 20 to $25 \mathrm{~m}$ (70 to $80 \mathrm{ft}$ ) (James and Blair, 1984). 
Jiusheng, (1997) found that for both circular and square nozzles, increasing pressure decreased droplet size in overall droplet spectra, and for a given pressure, changing nozzle shape from circular to square also decreased droplet size.

Frost and Schwalen (1960) investigated combined spray evaporation and drift losses, also by the catch-can method. A good correlation between spray losses and vapor- pressure deficit was obtained, and it was found that losses were approximately proportional to nozzle pressure and wind speed and inversely proportional to nozzle diameter. Seginer (1971) reported that as the number of droplets in the air increased and their size decreased, the total loss increased. The regression lines of total loss on solar radiation, for various operation conditions were practically parallel to each other with slope of about 0.5 .

Jiusheng Li and Hiroshi Kawano (1995) studied the water droplet movement in the air which is mainly affected by drag and gravity. They used the following equations of motion for an individual droplet under no-wind condition on a computer model.

$$
\begin{aligned}
& \frac{d^{2} x}{d t^{2}}=-3 / 4\left(\rho_{a} / \rho_{w}\right) \cdot\left(C_{d} / d\right) \cdot V \cdot V_{x} \\
& \frac{d^{2} z}{d t^{2}}=-3 / 4\left(\rho_{a} / \rho_{w}\right) \cdot\left(C_{d} / d\right) \cdot V \cdot V_{z}-g
\end{aligned}
$$

Where:

$x=$ position component in the horizontal direction in $\mathrm{m}$,

$z=$ position component in the vertical direction in $\mathrm{m}$,

$t=$ time in $\mathrm{s}$,

$V_{x}=d x / d t=$ horizontal component of velocity $\mathrm{V}$ in $\mathrm{m} / \mathrm{s}$, and

$V_{z}=d z / d t=$ vertical component of velocity $\mathrm{V}$ in $\mathrm{m} / \mathrm{s}$.

Equations (4) and (5) were solved by using Runge-Kutta fourth-order numerical scheme with the time step increment $(\Delta \mathrm{t})$ of $0.005 \mathrm{~s}$. Finally they predicted the droplet diameter at any distance from sprinkler for circular, square and double rectangular nozzle shapes.

They used the following initial conditions to solve equation (4) and (5) $\mathrm{x}(0)=0 ; \mathrm{z}(0)=$ riser height $(0.83 \mathrm{~m}) ; \mathrm{V}_{\mathrm{X}}(0)=\mathrm{V}(0) \cos \theta_{0} ; \mathrm{V}_{\mathrm{Z}}(0)=\mathrm{V}$ $\sin \theta_{0} ; \theta_{0}=$ sprinkler trajectory angle; $\mathrm{V}(0)=$ initial nozzle water velocity $(\mathrm{m} / \mathrm{s})$. 
A finite difference numerical model was developed by David and Yuping (1989) to determine the volume mean droplet diameter at any distance from a sprinkler as a function of nozzle size and pressure. The model was verified with sprinkler nozzle sizes $4.0 \mathrm{~mm}$ and $3.2 \mathrm{~mm}$ circular and 3.5 $\mathrm{mm}$ square nozzles. A total of 140 indoor tests were conducted with pressure between $69 \mathrm{kPa}(10 \mathrm{Psi})$ and $414 \mathrm{kPa}(60 \mathrm{Psi})$ at $28 \mathrm{kPa}$ (4Psi) increment.

Richards and Weatherhead (1993) studied the effect of wind and reported that wind elongated the pattern at right angles to the wind. The wetted distance downwind from the sprinkler increased as wind velocity increased but the increase was proportionately less than the increase in across wind wetted radius and wetted distance upwind.

The objective of this work is to develop, test, evaluate and verify a computer model to predict the droplet size diameter distribution.

\section{MATERIALS AND METHODS}

\section{THE MATHEMATICAL MODEL DEVELOPMENT:}

Seginer (1965) obtained a relationship between the empirical drag coefficient " $\mathrm{C}_{\mathrm{n}}$ " and droplet diameter as follows:

$$
\mathrm{C}_{\mathrm{n}}=0.4671 \mathrm{~d}^{-0.9859}
$$

Where:

$$
\mathrm{d}=\text { droplet diameter in } \mathrm{mm}
$$

Hills and Yuping (1989) used the following equations relating acceleration of water droplet in the horizontal and vertical directions respectively:

$$
\begin{aligned}
& A_{x}=-C_{n} V^{2} \cos \theta \\
& A_{y}=-C_{n} V^{2} \sin \theta-g
\end{aligned}
$$

Where:

$$
\begin{aligned}
& A_{x}=\text { acceleration component in } x \text { direction, } \mathrm{m} / \mathrm{s}^{2} . \\
& A_{y}=\text { acceleration component in y direction, } \mathrm{m} / \mathrm{s}^{2} . \\
& \mathrm{V}=\text { resultant velocity of droplet, } \mathrm{m} / \mathrm{s} .\left(\mathrm{V}=\sqrt{V_{x}^{2}+V_{y}^{2}}\right) \\
& \theta=\text { flight path inclination angle from horizontal }\left(\theta=\tan ^{-1} \mathrm{~V}_{\mathrm{y}} / \mathrm{V}_{\mathrm{x}}\right) . \\
& \mathrm{g}=\text { gravity acceleration, } 9.81 \mathrm{~m} / \mathrm{s}^{2} . \\
& \mathrm{V}_{\mathrm{x}}=\text { velocity component in } \mathrm{x} \text { direction, } \mathrm{m} / \mathrm{s} .\left(\mathrm{V}_{\mathrm{x}}=\mathrm{V} \cos \theta\right) . \\
& \mathrm{V}_{\mathrm{y}}=\text { velocity component in y direction, } \mathrm{m} / \mathrm{s} .\left(\mathrm{V}_{\mathrm{y}}=\mathrm{V} \sin \theta\right) .
\end{aligned}
$$


Equations 7 and 8 are rearranged and solved using a numerical finite difference approximation procedure with appropriate initial conditions. For a velocity at time step $i$; these equations become:

Where:

$$
\begin{aligned}
& V_{x}(i)=V_{x}(i-1)+A_{x}(i-1) \Delta t \\
& V_{y}(i)=V_{y}(i-1)+A_{y}(i-1) \Delta t
\end{aligned}
$$

$\mathrm{V}_{\mathrm{X}}(\mathrm{i}-1)=$ velocity component in $\mathrm{x}$ direction at time step (i-1), $\mathrm{m} / \mathrm{s}$.

$\mathrm{V}_{\mathrm{y}}(\mathrm{i}-1)=$ velocity component in $\mathrm{z}$ direction at time step (i-1), $\mathrm{m} / \mathrm{s}$.

$\mathrm{A}_{\mathrm{X}}(\mathrm{i}-1)=$ velocity component in $\mathrm{x}$ direction at time step (i-1), $\mathrm{m} / \mathrm{s}^{2}$.

$\mathrm{A}_{\mathrm{y}}(\mathrm{i}-1)=$ velocity component in $\mathrm{z}$ direction at time step (i-1), $\mathrm{m} / \mathrm{s}^{2}$.

$$
\Delta \mathrm{t}=\text { time step increment, } \mathrm{s} \text {. }
$$

Similarly, the droplet position at time step $\mathrm{i}$ is defined by the following equations:

$$
\begin{aligned}
& X(i)=X(i-1)+X(i-1) \Delta t \\
& Y(i)=Y(i-1)+Y(i-1) \Delta t
\end{aligned}
$$

Where:

$\mathrm{X}(\mathrm{i}-1)=$ position component in $\mathrm{x}$ direction at time step (i-1), $\mathrm{m} / \mathrm{s}$.

$\mathrm{Y}(\mathrm{i}-1)=$ position component in $\mathrm{z}$ direction at time step (i-1), $\mathrm{m} / \mathrm{s}$.

Equations (6) through (12) were used to develop a computer model to predict the droplet size diameter distribution. The input data were nozzle shape, nozzle dimensions, Trajectory angle, riser height, orifice coefficient, wind speed and direction. The flowchart of the model is illustrated in Fig. (1).

The initial conditions (at zero time) required to run the model, are as follows:

$$
\begin{aligned}
& \mathrm{X}(0)=0 \\
& \mathrm{Z}(0)=\text { riser height }(1 \mathrm{~m} \text { in this study }) \\
& \mathrm{V}(0)=\text { nozzle water velocity, } \mathrm{m} / \mathrm{s} \\
& \theta_{0}=\text { nozzle trajectory angle, deg } \\
& \mathrm{V}_{\mathrm{x}}(0)=\mathrm{V}(0) \cos \theta_{0}, \quad \mathrm{~V}_{\mathrm{y}}(0)=\mathrm{V}(0) \sin \theta_{0}
\end{aligned}
$$

A $0.1 \mathrm{~mm}$ droplet diameter increment was used starting from $0.1 \mathrm{~mm}$ to maximum droplet diameter. Finally the model gives the droplet diameter and its distance from sprinkler as an output.

\section{DATA GENERATION FOR THE MODEL:}


To generate the data required for the model, indoors lab test runs were conducted. The sprinkler system used an electric pump of $0.37 \mathrm{~kW}$ with $3 / 4$ inch inlet diameter and $3 / 4$ inch outlet diameter. The pipeline used was polyethylene pipe of $3 / 4$ inch nominal diameter. The riser height was 100 $\mathrm{cm}$. Riser was steel pipe of $3 / 4$ inch nominal diameter. The R.C. 160-S sprinkler was used in this study. The sprinkler material was plastic, full circle $3 / 4$ inches male pipe thread connection. The nozzle dimensions were square $(3.9 \mathrm{~mm})$, rectangle $(3 \mathrm{~mm}$ width $\times 5 \mathrm{~mm}$ height), isosceles triangle (5.5 mm - base and height) and circle ( $4.4 \mathrm{~mm}$ diameter) with trajectory angle $20^{\circ}$. The cross section areas of the four shapes are almost the same except of the very small fractions due to mathematical transformation from one shape to another. Moreover, the possibility of manufacturing these different shapes at the exact cross section areas. The Petri dishes used were $89 \mathrm{~mm}$ in diameter and $16 \mathrm{~mm}$ in height. Misr $10000 \mathrm{Km}$ oil was used in this study.

The droplet photographic instrument adopted illumination technique was used to measure the droplet size diameter. Nicon coolpix 5600 Digital Camera was used in the study to photo the Petri dishes with oil using close- up mode. It was 5.1 mega pixels and $3 \mathrm{X}$ zoom. The Image-Pro Plus for windows version 1.3 program was used in this study to measure the droplet diameter from the photos of Petri dishes with oil and water droplets.

Four levels of pressure were used: 138, 172.5, 207 and $240 \mathrm{kPa}(20,25$, 30 and 35 Psi). Four shapes of nozzles were tested: square, rectangle, triangle and circle. Testes were replicated 3 times. So, the total number of experiments was 48. Pressure was measured using the dial pressure gage 60 Psi $(414 \mathrm{kPa})$ with scale increment of 2 Psi $(13.8 \mathrm{kPa})$. The location of the pressure gage was fixed at $92.5 \mathrm{~cm}$ from the lateral as recommended by the $A S A B E$ standard (2006).

The duration of each replicate was one path only of the sprinkler. The water droplets were collected in Petri dishes filled with oil. To ensure credibility, the actual droplet diameter (Calculated by volume mean weight diameter procedure) was correlated to the measured ones (collected in the Petri dishes). The latter was determined via a digital 
camera and the Image Pro software. The following correlation was obtained

$$
\mathrm{ADSD}=0.99 \mathrm{MDSD}+0.0244
$$

Where:

$$
\begin{aligned}
& \text { ADSD }=\text { Actual droplet size diameter }, \mathrm{mm} \\
& \mathrm{MDSD}=\text { Measured droplet size diameter, } \mathrm{mm}
\end{aligned}
$$

Based on these results, very small difference was neglected and the actual droplet size diameter was assumed the same as the measured droplet diameter.

This model may be used only for zero wind condition. However, it was modified to be used in windy condition. 


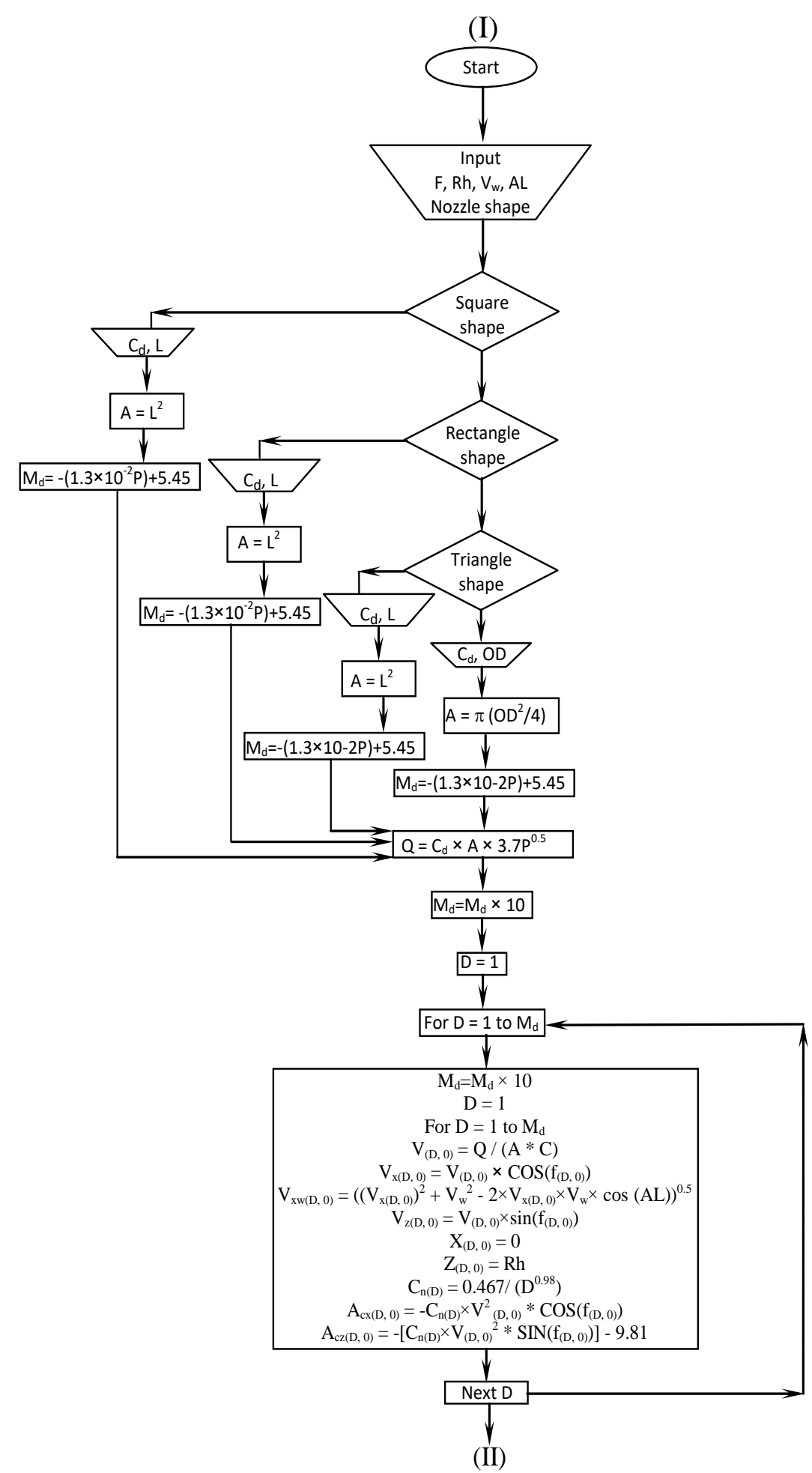

Figure (1): Flowchart of the developed computer model. 


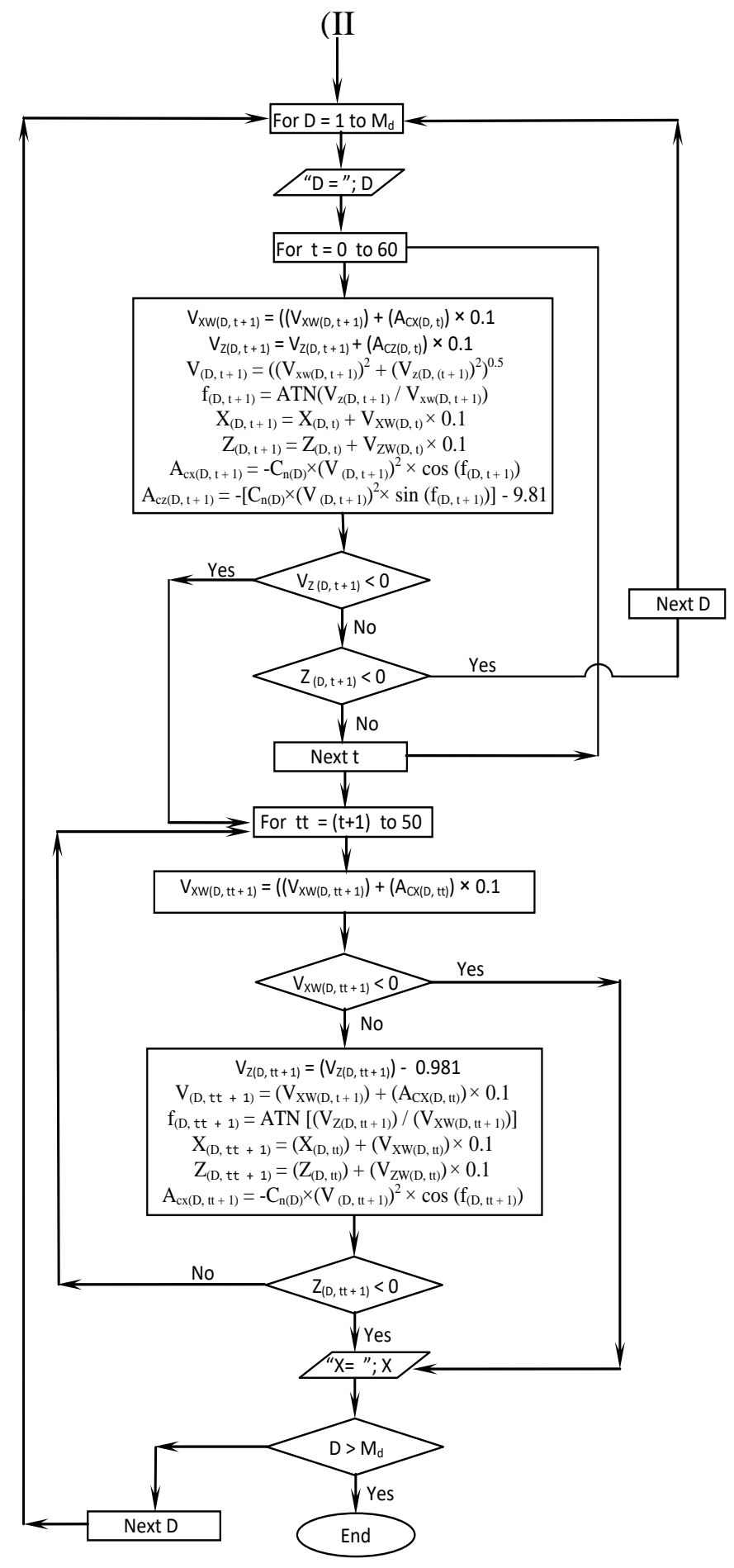

Cont. Figure (1): Flowchart of the developed computer model. 


\section{SIMULATING WIND EFFECT:}

During the sprinkler rotation the angle between wind direction and droplet movement direction $(\alpha)$ changed from $0^{\circ}$ to $360^{\circ}$. When $\alpha=0^{\circ}$ the resultant velocity $\left(\mathrm{V}_{\mathrm{xw}}\right)$ is the summation of water droplet velocity and wind velocity as shown in Figure (2). But when $\alpha=180^{\circ}$ as shown in Figure (3) the resultant velocity $\left(\mathrm{V}_{\mathrm{xw}}\right)$ is the difference between water droplet velocity and wind velocity. In general case when $0^{\circ}<\alpha<360^{\circ}$ as shown in Figure (4) $V_{x w}$ could be described by the following equation:

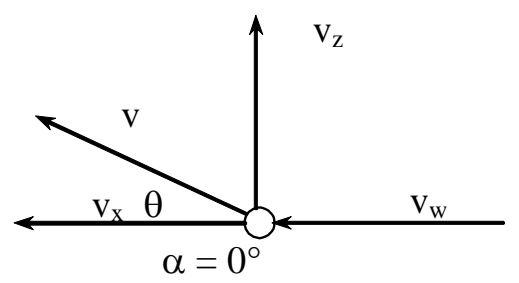

Figure (2): Wind direction with the same direction as droplet $\left(\alpha=\right.$ zero $\left.^{\circ}\right)$.

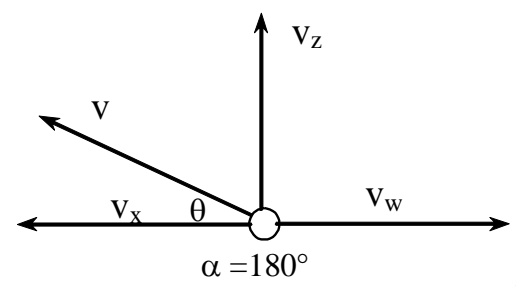

Figure (3): Wind direction with the opposite direction of droplet $\left(\alpha=180^{\circ}\right)$.

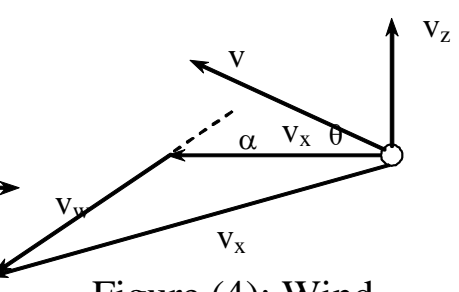

Figure (4): Wind direction with $\alpha$ angle direction of droplet.

$$
V_{x w}=\sqrt{v_{x}^{2}+v_{w}^{2}-2 v_{x} v_{w} \cos (180-\alpha)}
$$

Where:

$$
\begin{aligned}
& v_{x}=\text { Droplet velocity component in } \mathrm{x} \text { direction }\left(\mathrm{m} . \mathrm{s}^{-1}\right) \\
& v_{w}=\text { Wind velocity }\left(\mathrm{m} \cdot \mathrm{s}^{-1}\right) \\
& v_{x w}=\text { Droplet resultant velocity in } \mathrm{x} \text { direction for windy condition } \\
& \quad\left(\mathrm{m} \cdot \mathrm{s}^{-1}\right) \\
& v_{\mathrm{x}}=\mathrm{v} \operatorname{Cos} \theta \\
& \begin{array}{l}
\alpha=\underset{\text { deg. }}{\operatorname{angle}} \text { between wind direction and droplet movement direction }
\end{array}
\end{aligned}
$$

\section{MODEL VERIFICATION:}

To verify the model output, the predicated values were correlated to the measured values. A linear regression model of $\mathrm{Y}=\mathrm{A}+\mathrm{BX}$ was developed with the predicted droplet diameter as the dependent variable (Y) and the observed droplet diameter as the independent variable $(\mathrm{X})$. If the regression model was a perfect predictor of the droplet diameter, the 
linear regression constants (A) and (B) would equal 0 and 1, respectively. Gregory and Fedler (1986) stated that values or $\mathrm{R}^{2}$ (coefficient of determination) varies between 0 and 1 and provides an index of goodness of model fit. If $\mathrm{R}^{2}$ value is 0.90 or larger, then at least $90 \%$ of the variability is explained. This would generally be considered an excellent fit. On the other hand, an $\mathrm{R}^{2}$ value of 0.80 is considered a good fit. An $\mathrm{R}^{2}$ value as low as 0.60 is sometimes considered acceptable or even good. The evaluation of linear model of different shapes is based on values of $\mathrm{A}, \mathrm{B}, \mathrm{R}^{2}, \mathrm{R}$ and the standard error of estimation $(\lambda)$ which is defined below as:

$$
\lambda=\sqrt{\frac{\sum_{i=1}^{i=n}\left(D_{\text {Mes. }}-D_{\text {Pre. }}\right)^{2}}{n}}
$$

Where:

$D_{\text {Mes }}=$ Measured droplet diameter, $\mathrm{mm}$.

$D_{\text {Pre }}=$ Predicted droplet diameter, $\mathrm{mm}$.

$\lambda=$ Standard error of estimation

$n \quad=$ Number of observations.

The $\mathrm{R}^{2}$ and $\lambda$ (standard error of estimate linear model) indicate the scatter points about the regression equation. $\mathrm{R}$ (correlation coefficient) indicates the degree of association between the observed and predicted values. To assist further in this evaluation, another index called coefficient of efficient $\left(\mathrm{C}_{\mathrm{e}}\right)$ was used. This coefficient was proposed by Nash and Sutcliffe (1970) and used by Masheshwari and McMahon (1993), Zin El-Abedin and Ismail (1999) and Sharaf (2003). If $\mathrm{R}$ and $\mathrm{C}_{\mathrm{e}}$ are close to each other, the model is free from any bias all or part of the data. $\mathrm{C}_{\mathrm{e}}$ is defined below as:

$$
C_{e}=\frac{\sum_{i=1}^{i=n}\left(X_{o i}-\bar{X}_{o}\right)^{2}-\sum_{i=1}^{i=n}\left(X_{o i}-X_{p i}\right)}{\sum_{i=1}^{i=n}\left(X_{o i}-\bar{X}_{o}\right)^{2}}
$$

Where:

$\mathrm{C}_{\mathrm{e}}=$ coefficient of efficient

$\mathrm{n}=$ number of observations

$\mathrm{X}_{\mathrm{oi}}=\mathrm{i}^{\text {th }}$ value of observed measurements, $\mathrm{mm}$.

$\bar{X}_{o}=$ average observed value, $\mathrm{mm}$.

$\mathrm{X}_{\mathrm{pi}}=\mathrm{i}^{\mathrm{th}}$ value of predicted measurements, $\mathrm{mm}$.

Misr J. Ag. Eng., January 2009 


\section{RESULTS AND DISCUSSION}

The arithmetic mean droplet size distribution from data generation experiment results for different nozzle orifice shapes and sprinkler base pressures are shown in following Table.

Table (1): Arithmetic mean droplet size diameter $(\mathrm{mm})$ for different nozzle orifice shapes and sprinkler base pressures along the throw.

\begin{tabular}{|c|c|c|c|c|c|c|c|c|}
\hline \multirow{2}{*}{$\begin{array}{c}\text { Sprinkler base } \\
\text { pressure, } \mathrm{kPa}\end{array}$} & \multirow{2}{*}{$\begin{array}{l}\text { Nozzle } \\
\text { orifice } \\
\text { shape }\end{array}$} & \multicolumn{7}{|c|}{ Distance from sprinkler, $\mathrm{m}$} \\
\hline & & 1 & 3 & 5 & 7 & 9 & 11 & 13 \\
\hline \multirow{4}{*}{137.0} & Circular & $\begin{array}{c}0.3 \\
7\end{array}$ & $\begin{array}{c}0.7 \\
8\end{array}$ & $\begin{array}{c}1.3 \\
1\end{array}$ & 1.5 & 2.8 & $\begin{array}{c}3.7 \\
6\end{array}$ & \\
\hline & Square & $\begin{array}{c}0.7 \\
8\end{array}$ & $\begin{array}{c}0.9 \\
8\end{array}$ & $\begin{array}{c}1.3 \\
8\end{array}$ & $\begin{array}{c}2.5 \\
8\end{array}$ & $\begin{array}{c}3.0 \\
8\end{array}$ & & \\
\hline & Rectangular & $\begin{array}{c}0.6 \\
5\end{array}$ & $\begin{array}{c}0.9 \\
7\end{array}$ & $\begin{array}{c}1.5 \\
3\end{array}$ & $\begin{array}{c}2.3 \\
9\end{array}$ & & & \\
\hline & Triangular & $\begin{array}{c}0.5 \\
1\end{array}$ & $\begin{array}{c}0.9 \\
1\end{array}$ & $\begin{array}{c}1.5 \\
1\end{array}$ & $\begin{array}{c}2.4 \\
7\end{array}$ & & & \\
\hline \multirow{4}{*}{172.5} & Circular & $\begin{array}{c}0.3 \\
1\end{array}$ & $\begin{array}{c}0.7 \\
7\end{array}$ & $\begin{array}{c}1.2 \\
8\end{array}$ & $\begin{array}{c}1.3 \\
2\end{array}$ & $\begin{array}{c}2.3 \\
9\end{array}$ & $\begin{array}{c}3.0 \\
4\end{array}$ & \\
\hline & Square & $\begin{array}{c}0.4 \\
8\end{array}$ & $\begin{array}{c}0.8 \\
5\end{array}$ & $\begin{array}{c}1.3 \\
1\end{array}$ & $\begin{array}{c}1.9 \\
7\end{array}$ & $\begin{array}{c}2.8 \\
3\end{array}$ & & \\
\hline & Rectangular & $\begin{array}{c}0.4 \\
7\end{array}$ & $\begin{array}{c}0.8 \\
9\end{array}$ & $\begin{array}{c}1.3 \\
3\end{array}$ & $\begin{array}{c}2.0 \\
8\end{array}$ & $\begin{array}{c}2.2 \\
7\end{array}$ & & \\
\hline & Triangular & $\begin{array}{c}0.5 \\
1\end{array}$ & $\begin{array}{c}0.8 \\
3\end{array}$ & $\begin{array}{c}1.3 \\
6\end{array}$ & $\begin{array}{c}1.9 \\
8\end{array}$ & 2.4 & & \\
\hline \multirow{4}{*}{207.0} & Circular & 0.3 & $\begin{array}{c}0.7 \\
3\end{array}$ & $\begin{array}{c}0.9 \\
4\end{array}$ & $\begin{array}{c}1.1 \\
1\end{array}$ & $\begin{array}{c}1.5 \\
5\end{array}$ & 2.4 & $\begin{array}{c}2.8 \\
3\end{array}$ \\
\hline & Square & $\begin{array}{c}0.4 \\
3\end{array}$ & $\begin{array}{c}0.7 \\
7\end{array}$ & $\begin{array}{c}1.2 \\
7\end{array}$ & $\begin{array}{c}1.7 \\
1\end{array}$ & $\begin{array}{c}2.6 \\
2\end{array}$ & & \\
\hline & Rectangular & $\begin{array}{c}0.4 \\
4\end{array}$ & $\begin{array}{c}0.7 \\
7 \\
\end{array}$ & $\begin{array}{c}1.2 \\
6 \\
\end{array}$ & $\begin{array}{c}1.5 \\
7\end{array}$ & $\begin{array}{c}2.2 \\
1\end{array}$ & & \\
\hline & Triangular & 0.5 & 0.8 & $\begin{array}{c}1.3 \\
5\end{array}$ & $\begin{array}{c}1.6 \\
8\end{array}$ & $\begin{array}{c}2.3 \\
1\end{array}$ & & \\
\hline \multirow{4}{*}{241.5} & Circular & $\begin{array}{c}0.2 \\
6\end{array}$ & $\begin{array}{c}0.6 \\
9\end{array}$ & $\begin{array}{c}0.8 \\
6\end{array}$ & $\begin{array}{c}0.9 \\
9\end{array}$ & $\begin{array}{c}1.2 \\
9\end{array}$ & $\begin{array}{c}2.0 \\
4\end{array}$ & $\begin{array}{c}2.3 \\
4\end{array}$ \\
\hline & Square & $\begin{array}{c}0.4 \\
1\end{array}$ & $\begin{array}{c}0.7 \\
7\end{array}$ & $\begin{array}{c}1.0 \\
8\end{array}$ & 1.5 & $\begin{array}{c}2.1 \\
2\end{array}$ & & \\
\hline & Rectangular & $\begin{array}{c}0.3 \\
8\end{array}$ & $\begin{array}{c}0.7 \\
7\end{array}$ & $\begin{array}{c}1.0 \\
5\end{array}$ & $\begin{array}{c}1.2 \\
6\end{array}$ & $\begin{array}{c}2.0 \\
8\end{array}$ & & \\
\hline & Triangular & $\begin{array}{c}0.4 \\
8\end{array}$ & 0.8 & $\begin{array}{c}1.0 \\
5\end{array}$ & $\begin{array}{c}1.6 \\
1\end{array}$ & 2.2 & & \\
\hline
\end{tabular}




\section{MAXIMUM DROPLET SIZE DIAMETER:}

The model requires the maximum droplet size diameter for each orifice shape and sprinkler base pressure. Using previous indoor lab testes results in the following linear equations developed to describe the relationship between maximum droplet size diameter and sprinkler base pressure for circular, square, rectangular and triangular orifice shapes respectively.
For circle
$: \mathrm{MD}=-0.0130 \mathrm{Pr}+5.45$
$\mathrm{R}^{2}=0.96$
For square
$: \mathrm{MD}=-0.0089 \mathrm{Pr}+4.36$
$\mathrm{R}^{2}=0.96$
For rectangle $: \mathrm{MD}=-0.0028 \mathrm{Pr}+2.77$
$\mathrm{R}^{2}=0.99$
For triangle $\quad: \mathrm{MD}=-0.0025 \mathrm{Pr}+2.81$
$\mathrm{R}^{2}=0.99$

Where:

$$
\begin{aligned}
& \mathrm{MD}=\text { Maximum droplet size diameter, } \mathrm{mm} \\
& \mathrm{Pr}=\text { Sprinkler base pressure }, \mathrm{kPa}
\end{aligned}
$$

\section{1- For different orifice shapes:}

A graphical comparison of the measured versus predicted droplet size diameter for different shapes; circle, square, rectangle and triangle are given in Figure (5).

In general, the value of $\mathrm{B}$ is close to 1 and $\mathrm{A}$ close to zero, accompanied by low $\lambda$ and high $\mathrm{R}^{2}, \mathrm{R}$ and $\mathrm{C}_{\mathrm{e}}$ values, would indicate satisfactory prediction by the model. Because the slope B and the intercept A are significantly different from 1.0 and 0, respectively, at the $99 \%$ level of confidence, a bias exists within the model estimation. This bias oscillates between over and less estimation which depends mainly on A and $\mathrm{B}$ values. The results of this evaluation along with the statistical parameters for droplet diameters are given in Tab. (2)

Table (2): Indices of the different orifice shapes

in predicting droplet diameter.

\begin{tabular}{|c|c|c|c|c|}
\hline Parameter & Circle & Square & Rectangle & Triangle \\
\hline $\mathrm{n}$ & 18 & 16 & 15 & 15 \\
\hline $\mathrm{A}$ & 0.842 & 0.818 & 0.839 & 0.802 \\
\hline $\mathrm{B}$ & 0.233 & 0.382 & 0.311 & 0.334 \\
\hline $\mathrm{C}_{\mathrm{e}}$ & 0.912 & 1.142 & 1.232 & 1.083 \\
\hline $\mathrm{R}^{2}$ & 0.949 & 0.968 & 0.935 & 0.957 \\
\hline $\mathrm{R}$ & 0.974 & 0.984 & 0.967 & 0.978 \\
\hline$\lambda$ & 0.217 & 0.191 & 0.168 & 0.155 \\
\hline
\end{tabular}




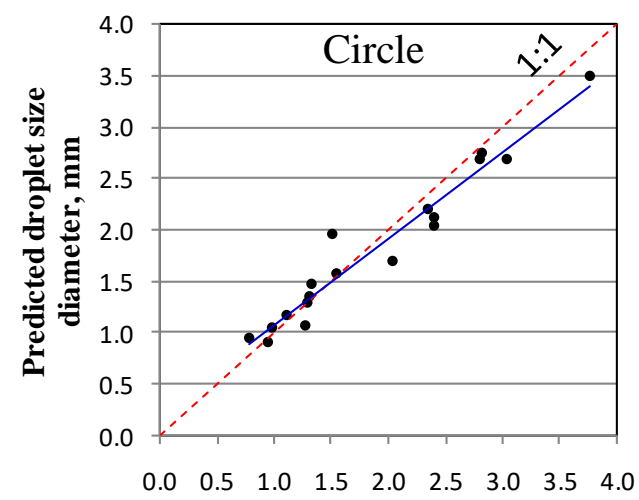

Observed droplet size diameter, $\mathbf{m m}$

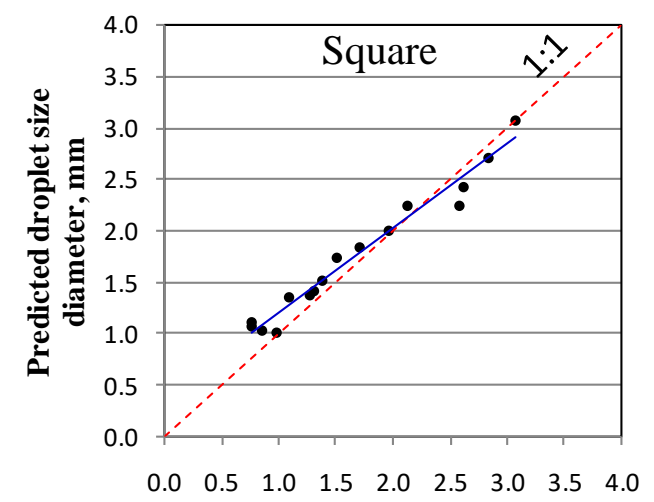

Observed droplet size diameter, $\mathbf{m m}$

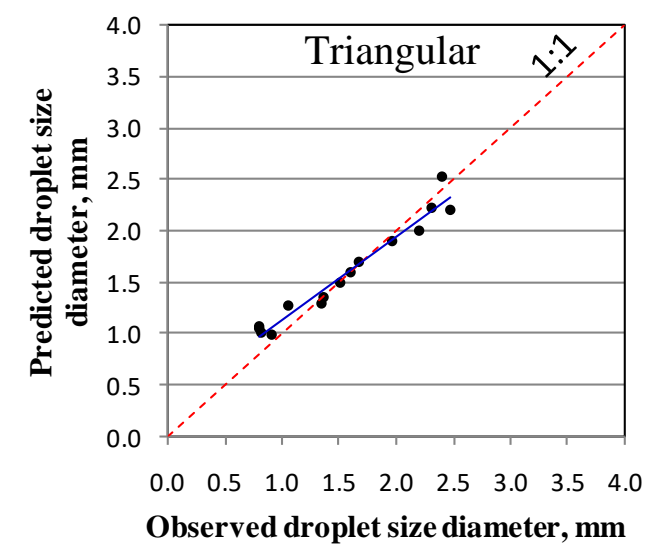

Observed droplet size diameter, mm

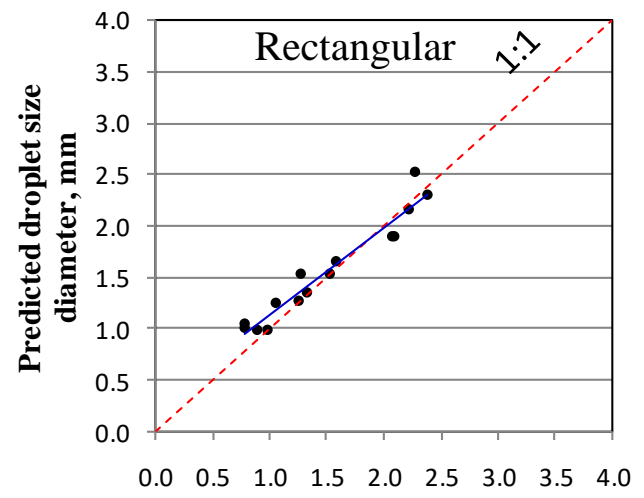

Observed droplet size diameter, $\mathbf{m m}$
Figure (5): Verification of droplet size diameter for different orifice shapes.

Misr J. Ag. Eng., January 2009 
Considering the value of various indices of evaluating the four shapes, one can find that $R^{2}$ values for all shapes are greater than 0.93 and $C_{e}$ values are close to $R^{2}$. The value of $A$ and $B$ are closer to 1 and 0 respectively. Furthermore, $\mathrm{R}^{2}$ values are high, less difference between $\mathrm{R}^{2}$ and $\mathrm{C}_{\mathrm{e}}$ and $\lambda$ values are minimal.

In general, the correlation between the observed and predicted droplet diameter values for all shapes is satisfactory. This indicates that the model output is appropriate and the bias existing within the shapes can be attributed to the experimental errors, manufacturer variation and uncalculated factors.

\section{2- For different sprinkler base pressures:}

A graphical comparison of the measured versus predicted droplet diameters for different sprinkler base pressures $138 \mathrm{kPa}, 172.5 \mathrm{kPa}, 207$ $\mathrm{kPa}$ and $241.5 \mathrm{kPa}$ are given in Figure (6).

In general, the value of $\mathrm{B}$ was close to 1 and $\mathrm{A}$ close to zero, accompanied by low $\lambda$ and high $\mathrm{R}^{2}, \mathrm{R}$ and $\mathrm{C}_{\mathrm{e}}$ values, would indicate satisfactory prediction by the model. Because the slope $\mathrm{B}$ and the intercept $\mathrm{A}$ are not significantly different from 1.0 and 0 , respectively, at the $99 \%$ level of confidence, a bias exists within the model estimation. This bias oscillates between over and less estimation which depends mainly on A and B values. The results of this evaluation along with the statistical parameters for droplet diameters are given in Tab. (3)

Considering the value of various indices of evaluating the four shapes, one can find that $\mathrm{R}^{2}$ values for all sprinkler base pressures are greater than 0.91 and $C_{e}$ values are close to $R^{2}$. The value of $A$ and $B$ are close to 1 and 0 respectively. Moreover, $\mathrm{R}^{2}$ values are high, less difference between $\mathrm{R}^{2}$ and $\mathrm{C}_{\mathrm{e}}$ and $\lambda$ values are minimal.

Table (3): Indices of the different sprinkler base pressures in predicting droplet diameter.

\begin{tabular}{|c|c|c|c|c|}
\hline Parameter & $138 \mathrm{kPa}$ & $172.5 \mathrm{kPa}$ & $207 \mathrm{kPa}$ & $241.5 \mathrm{kPa}$ \\
\hline $\mathrm{n}$ & 15 & 16 & 17 & 16 \\
\hline $\mathrm{A}$ & 0.863 & 0.852 & 0.817 & 0.597 \\
\hline $\mathrm{B}$ & 0.246 & 0.251 & 0.322 & 0.519 \\
\hline $\mathrm{C}_{\mathrm{e}}$ & 0.990 & 0.985 & 1.073 & 1.296 \\
\hline $\mathrm{R}^{2}$ & 0.964 & 0.937 & 0.971 & 0.913 \\
\hline $\mathrm{R}$ & 0.982 & 0.968 & 0.985 & 0.956 \\
\hline$\lambda$ & 0.189 & 0.181 & 0.151 & 0.218 \\
\hline
\end{tabular}


In general, the correlation between the observed and predicted droplet diameter values for low sprinkler base pressures $138 \mathrm{kPa}, 172.5 \mathrm{kPa}$ and $207 \mathrm{kPa}$ are more satisfactory than the high pressure of $241.5 \mathrm{kPa}$.

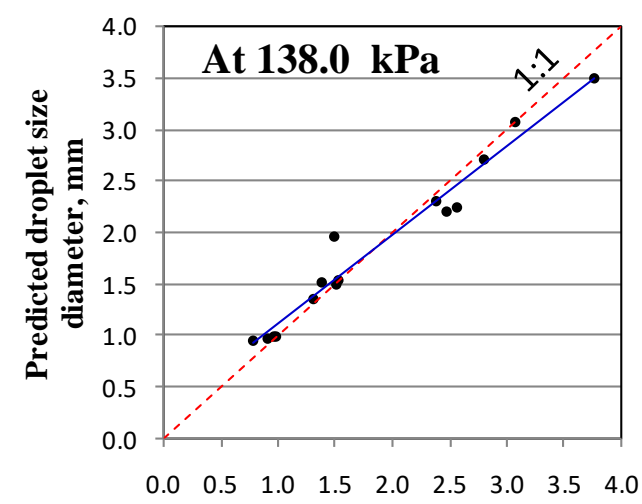

Observed droplet size diameter, $\mathbf{m m}$

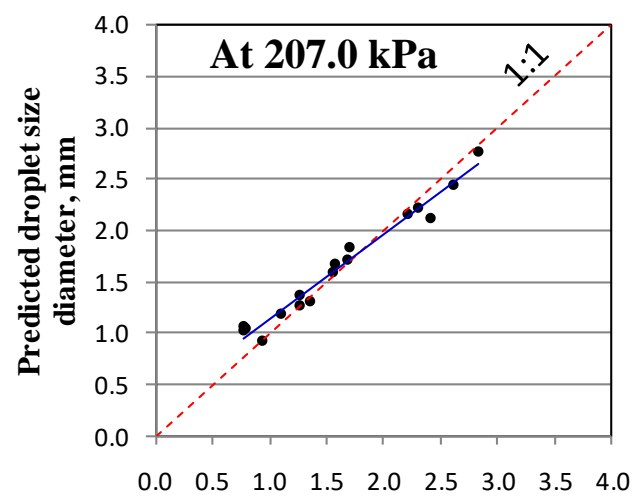

Observed droplet size diameter, $\mathbf{m m}$

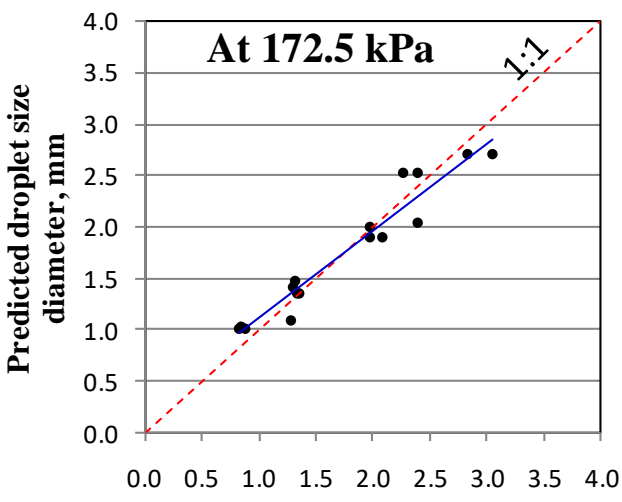

Observed droplet size diameter, $\mathbf{m m}$

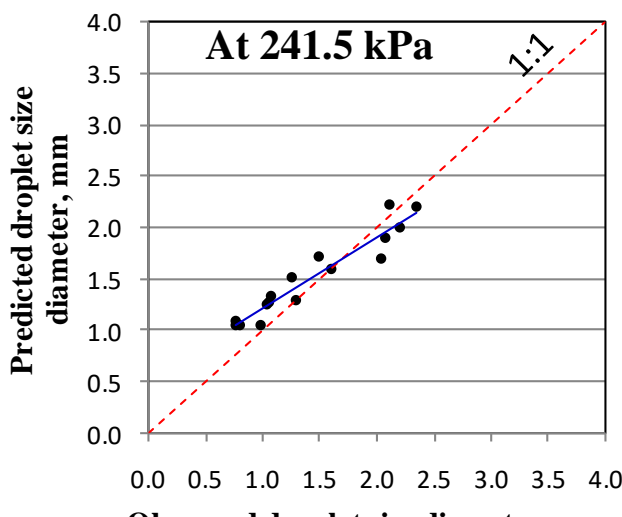

Observed droplet size diameter, $\mathbf{m m}$

Figure (6): Verification of droplet size diameter for different Sprinkler base pressures.

Misr J. Ag. Eng., January 2009 


\section{CASE STUDY}

The objectives of this case study were to:

1- Compare the droplet size distribution model prediction in zero and windy conditions.

2- $\quad$ Predict the wetted pattern shape in zero and windy conditions.

The computer model was used to simulate the effect of wind speed on droplet size distribution in windy conditions (up and down wind). Wind elongated the pattern at right angles to the wind (i.e. crosswind). The wetted distance downwind from the sprinkler (B) increased as wind velocity increased but the increase was proportionally less than the decrease in wetted distance upwind (A) (Table 4 and Figures 7 and 8). As a result, increasing wind velocity decreased the wetted area. The previous results agree with those obtained by Richards and Weatherhead (1993). Figure (7) is showing the difference between droplet size distribution at zero and windy conditions (i.e. 1, 2, 3 and $4 \mathrm{~m} / \mathrm{s}$ ) for the triangular orifice nozzle shape.

The model also can predict the droplet size distribution at any wind direction overall the irrigated pattern. Also the model can predict the shape of the wetted pattern at zero and windy conditions. The model was run at different wind speeds and $0^{\circ}$ to $360^{\circ}$ wind direction with interval of $10^{\circ}$ to get the maximum throw. The angle (wind direction) and maximum throw were used to draw the pattern shape using the Autocad software. Figure (8) illustrates the wetted perimeter from zero to $10 \mathrm{~m} / \mathrm{s}$ wind speed.

Table (4): distance up and down wind from the sprinkler with different wind speeds.

\begin{tabular}{|c|c|c|}
\hline Wind speed, $\mathrm{m} / \mathrm{s}$ & $\begin{array}{c}\text { distance upwind, } \mathrm{mm} \\
(\mathrm{A})\end{array}$ & $\begin{array}{c}\text { distance downwind, } \mathrm{mm} \\
(\mathrm{B})\end{array}$ \\
\hline 1 & 0.46 & 0.44 \\
\hline 2 & 0.96 & 0.86 \\
\hline 3 & 1.49 & 1.25 \\
\hline 4 & 2.07 & 1.62 \\
\hline
\end{tabular}




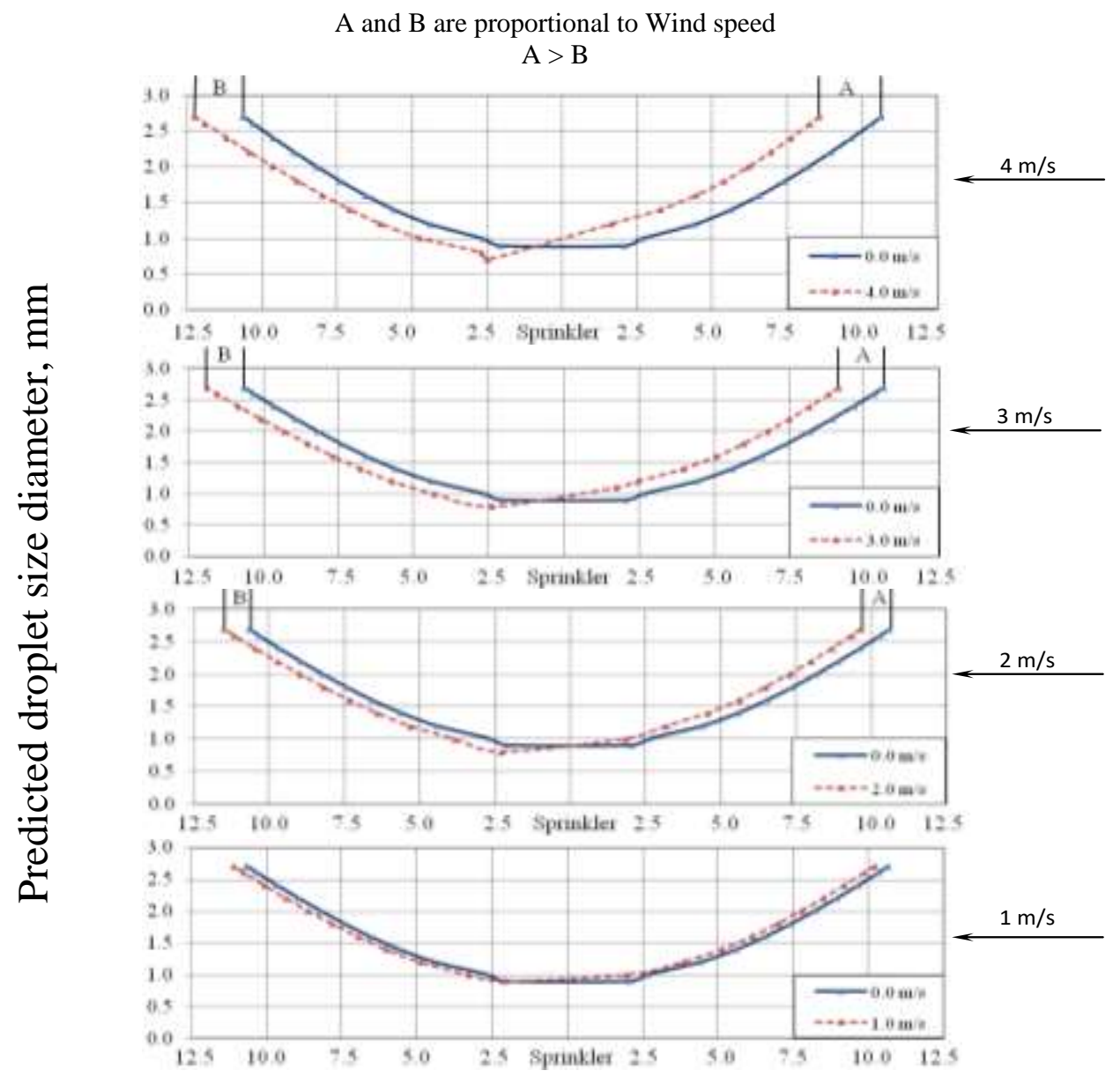

Figure (7): Effect of wind speed on droplet size distribution compared with zero wind condition. 


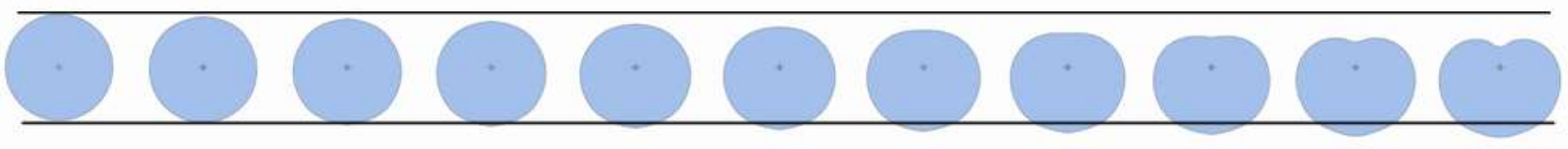

\section{$0 \mathrm{~m} / \mathrm{s} \quad 1 \mathrm{~m} / \mathrm{s} \quad 2 \mathrm{~m} / \mathrm{s} \quad 3 \mathrm{~m} / \mathrm{s} \quad 4 \mathrm{~m} / \mathrm{s} \quad 5 \mathrm{~m} / \mathrm{s} \quad 6 \mathrm{~m} / \mathrm{s} \quad 7 \mathrm{~m} / \mathrm{s} \quad 8 \mathrm{~m} / \mathrm{s} \quad 9 \mathrm{~m} / \mathrm{s} \quad 10 \mathrm{~m} / \mathrm{s}$}
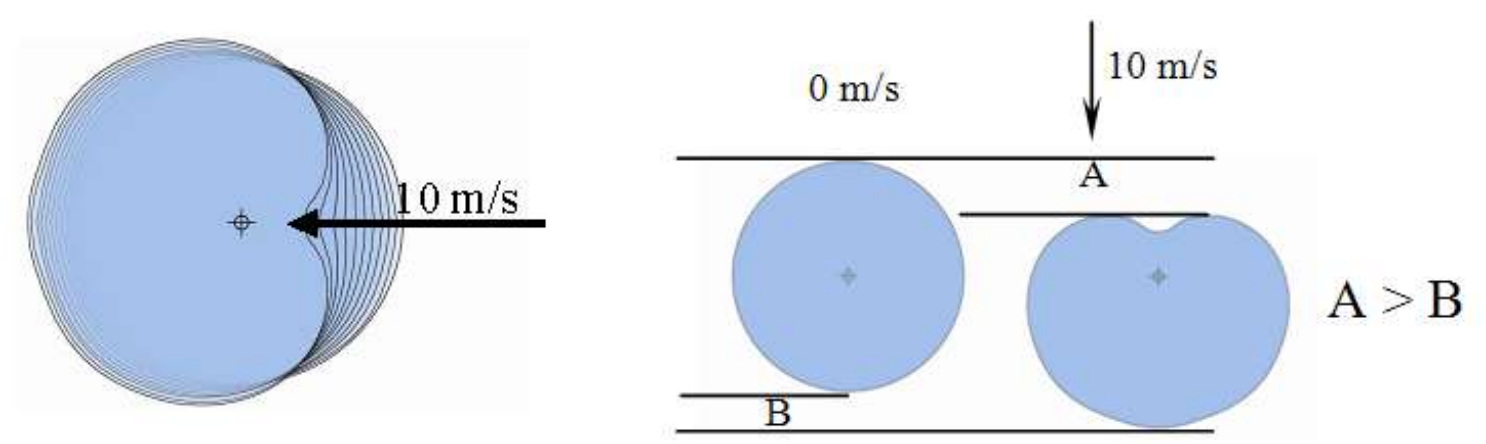

Figure (8): Effect of wind speed on application pattern from zero to $10 \mathrm{~m} / \mathrm{s}$ wind speed and intervals of $1 \mathrm{~m} / \mathrm{s}$. 


\section{CONCLUSIONS}

A computer model was developed to predict the droplet size distribution with zero and windy conditions. The model was Verified for different orifice shapes (circle, square, rectangular and triangle) and different pressures (138.0, 172.5, 207.0 and $241.5 \mathrm{kPa}$ ). The best results of the computer model predictions were achieved with triangular and rectangular nozzles; then with square and finally circular nozzle. For working pressures; the best results were attained at 207.0 and $172.5 \mathrm{kPa}$ then $138.0 \mathrm{kPa}$ and finally $241.5 \mathrm{kPa}$. In general, the correlation between the observed and predicted droplet size diameter values for all sprinkler base pressures and shapes is quite good. The model was used to predict the pattern shape in no wind and windy conditions. Wind elongated the pattern at right angles to the wind. The wetted distance downwind from the sprinkler increased as wind velocity increased but the increase was proportionally less than the decrease in wetted distance upwind. As a result, increasing wind velocity decreased the wetted area.

\section{REFERANCES}

ASABE Standards 2006. Standards Engineering Practices Data. Procedure for sprinkler testing and performance reporting. S398.1. PP 933-935.Adopted and published by the American Society of Agricultural and Biological Engineers. 53rd. Edition. ASABE, St.Joseph, MI, USA.

Awady, M. N. 1978. An atomization theory for swirl nozzles, Trans. of the ASAE 21 (1): 70-74.

Chen, D.and W. W. Wallender. 1985. Droplet size distribution and water application with low-pressure sprinklers. Trans. of the ASAE 28 (2): 511516.

Hills, D.J. and Yuping Gu, 1989. Sprinkler volume mean droplet diameter as a function of pressure. Trans. of the ASAE 32 (2): 471-476.

Forst, K.R. and H.C. Schwalen 1960. Evapotranspiration sprinkler irrigation. Trans. of the ASAE 3 (1): 18-20.24.

Gregory,J.M. and C.B. Fedler, 1986. Model evaluation and research verification (MERV). ASAE Paper No. 86-5032.

Heernann, D.F. and R.A. Kohl, 1981. Fluid dynamics of sprinkler systems. P: 583-618 Cited from Design and operation of farm irrigation systems. 859 
P. Ed. M. E. Jensen. An ASAE Monograph, No.3, ASAE, 2950 Niles Rd. St. Joseph MI, USA.

James L.G. and Blair S.K. 1984. Performance of low pressure center pivot systems. Trans. of the ASAE 27(6):1753-1757.

Jiusheng Li and Hiroshi Kawano, 1995. Simulating water-droplet movement from noncircular sprinkler nozzles. J. Irrig. Drain. Div. ASCE 121 (2): 152-185.

Jiusheng Li, 1997. Effect of pressure and nozzle shape on the characteristics of sprinkler droplet spectra. J. Agric. Eng. Research, Vol. 66, no. 1: 15-21.

Kohl, R. A. 1974 . Droplet size distribution from medium-size agricultural sprinklers. Trans. of the ASAE 17 (4): 690-693.

Larry G. james 1988. Principles of farm irrigation system design. 541: P. $192,197$.

Maheshwari, B. L. and T. A. Mcmahon, 1993. Performance evaluation of border irrigation models for south-east Australia: Part I, Advance and Recession characteristics. J. of Ag. Eng. Res. 54: 67-87.

Nash, J.E. and J.V. Sutcliffe, 1970. River flow forecasting through conceptual models. I.A. discussion of principles. J. of Hydrology, 10: 282-324.

Richards, P. J. and E.K. Weatherhead. 1993. Prediction of rain gun application patterns in windy conditions. J. Agric. Eng. Research 54(4): 281-291

Seginer, I. 1965. Tangential velocity of sprinkler drops. Trans. of the ASAE 3 (1): 90-93.

Seginer, I. 1971. Water losses during sprinkling. Trans. of the ASAE 14 (4): 656- 659, 664.

Sharaf, G.A. 2003. Evaluation of pressure distribution and lateral flow rates along drip tape lateral. J. Agric. Eng., Research 20(2): 542-556.

Zin El-Abedin, T. K. and S. M. Ismail, 1999. Estimation and analysis of water advance in surface irrigation. Misr J. Ag. Eng., 16 (4): 720-744. 


\section{الملخص العربي}

\section{برنامج بالحاسب الاككتروني للتتبؤ بمسافة سقوط قطر ات اتلفيكات المياه في ظروف انعدام

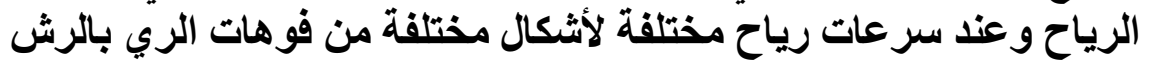

\section{عزمي البري'، محمود هانئ رمضان ‘، محسن عبد السلام العدلّ، هاثم محمد عبدالمجياء}

نظر اً لتأثير حجم القطر ات الكبير على سطح التربة. وزيادة نسبة الفاقد بالبخر و الرياح للقطر ات الصغيرة

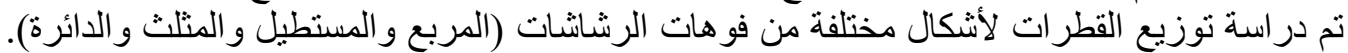

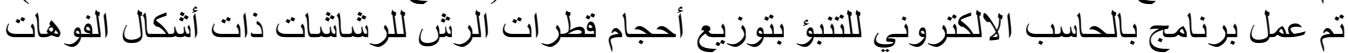

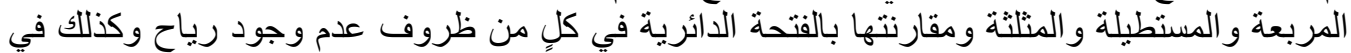

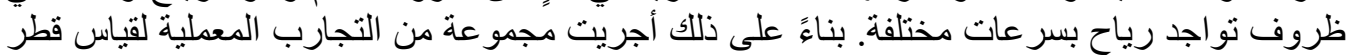

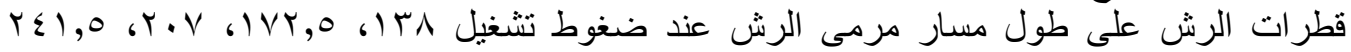

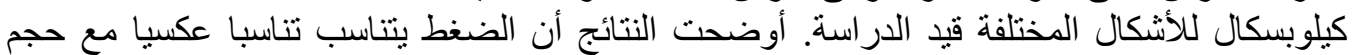

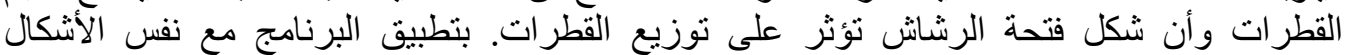

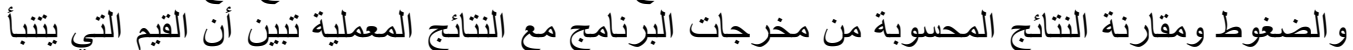

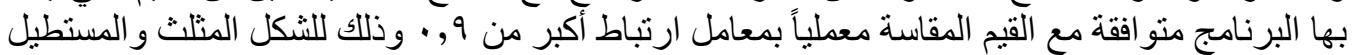

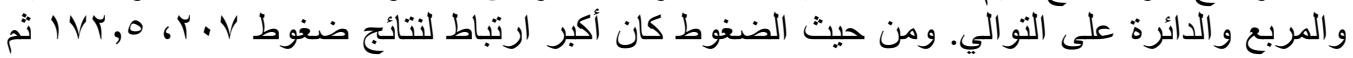

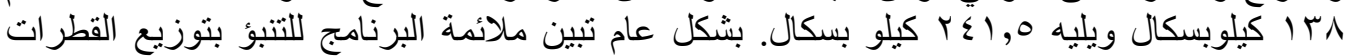

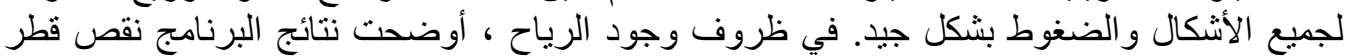

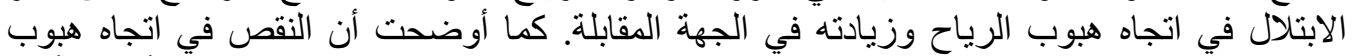

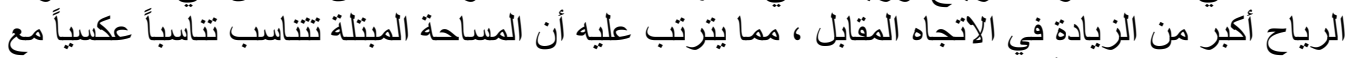

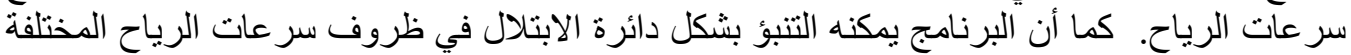

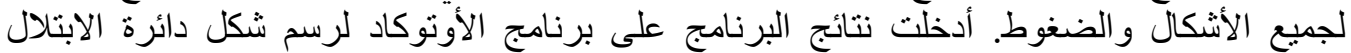

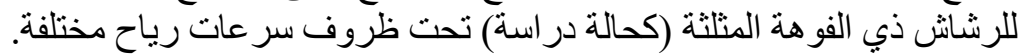

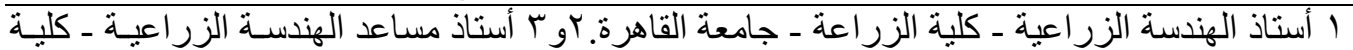

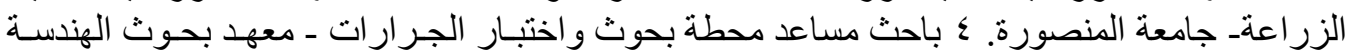
الزراعية - وزارة الزعة جاعة المنورة 